\title{
Life and Medical Sciences
}

\author{
Klinik ve Subklinik Hipotiroidili Hastalarda Hormon Regülasyonunun Hastanın \\ Yaşam Kalitesi, Ruhsal Durum ve Öfke Kontrolü Üzerine Etkisi \\ The Effect of Hormone Regulation on the Patient's Quality of Life, Mood, and
Anger Control in Patients with Clinical and Subclinical Hypothyroidism
} Süleyman ŞAHİNER ${ }^{1}[\mathrm{ID}]$, Oktay SARI ${ }^{1}[\mathrm{ID}]$

${ }^{1}$ Sağlık Bilimleri Üniversitesi, Gülhane Eğitim ve Araştırma Hastanesi, Aile Hekimliği Anabilim Dalı, Ankara, Türkiye [Department of Family Medicine, Gulhane Training and Research Hospital, University of Health Sciences, Ankara, Turkey].

Article Info: Received; 11.11.2011. Accepted; 06.12.2021. Published; 07.12.2021.

Correspondence: Oktay Sarı; Assoc.Prof., Department of Family Medicine, Gulhane Training and Research Hospital, University of Health Sciences, Ankara, Turkey. E-mail: oktay.sari@sbu.edu.tr

Cite as: Şahiner S, Sarı O. The Effect of Hormone Regulation on the Patient's Quality of Life, Mood, and Anger Control in Patients with Clinical and Subclinical Hypothyroidism. Life Med Sci 2022; 1(2): 36-46.

\section{Özet}

Klinik ve subklinik hipotiroidi hastalığı ile anksiyete ve depresyon sık birliktelik göstermektedir. Bu durum hastaların yaşam kalitelerini ve ruhsal durumlarını da olumsuz olarak etkilemektedir. Böyle olgularda, hormon replasman tedavisi ile hastaların yaşam kalitesinde ve ruhsal durumunda düzelmeler olabilmektedir. Çalışmamızın amacı klinik ve subklinik hipotiroidi hastalarında hormon regülasyonunun, yaşam kalitesi, ruhsal durum ve öfke kontrolü üzerine etkinliğini araştırmaktır. Çalışmaya dahil edilen 82 hipotiroidi hastasına, Hastane Anksiyete ve Depresyon ölçeği (HAD), EQ-5D genel yaşam kalite ölçeği, İlaç Uyum Bildirim Ölçeği (IUBÖ) ve saldırganlık ölçeğinden oluşan bir anket formu uygulandı. Hastaların tiroid fonksiyon testleri (TSH ve ST4) kaydedildi. Hastalara tedavi planlandıktan en az 3 hafta sonra olmak üzere TSH regülasyonlarının sağlandığı ilk kontrole gelişlerinde anket formu tekrar uygulandı. Hastaların yaş ortalaması $40.8 \pm 13.4$ idi. Katılımcıların \%69.5'i $(n=57)$ kadınlardan ve \%57.3'ü $(n=47)$ subklinik hipotiroidi vakalarından oluşuyordu. Tedavi öncesi dönemde klinik ve subklinik hipotiroidi hasta grupları arasında yaş ortalamaları, cinsiyet, eğitim düzeyleri ve diğer sosyodemografik veriler açısından anlamlı bir fark yoktu. Klinik hipotiroidi hasta grubunda anksiyete belirtisi \%40 ve depresyon belirtisi \%37.1 oranında bulunurken subklinik hipotiroidi hasta grubunda anksiyete belirtisi \%31.9 ve depresyon belirtisi \%23.4 oranında bulundu. Depresyon düzeyleri ile TSH düzeyleri arasında pozitif, ST4 düzeyleri arasında ise negatif yönde zayıf düzeyde anlamlı ilişki bulundu. Yaşam kalitesi ve saldırganlık düzeyleri ile TSH ve sT4 arasında istatistiksel olarak anlamlı bir ilişki bulunamadı. Tedavi öncesi ve sonrası dönem karşılaştırıldığında her iki hasta grubunda da anksiyete, depresyon ve saldırganlık düzeyi ortalama skorlarında anlamlı düşüşler saptandı. Yaşam kalitesi ölçek skorlarında ise tedavi sonrasında anlamlı düzeyde artış görüldü. Klinik hipotiroidili hastaların ilaç uyum skorlarında tedavi öncesi ve sonrası arasında anlamlı bir farklıık görülmezken, subklinik hipotiroidili hastalarda anlamlı farklılıklar saptandı. Her iki gruptaki hastaların hormon replasman tedavisi sonrasında, depresyon ve anksiyete riski ile saldırganlık düzeylerinde azalma, yaşam kalitelerinde ise artış görüldü. Aile hekimliği pratiğinde hasta şikayetleri değerlendirilirken biyopsikososyal yaklaşım göz önünde bulundurularak, klinik ve subklinik hipotiroidide psikiyatrik belirtilerin sık görüldüğü, hipotiroidinin bazen psikiyatrik belirtilerle ortaya çıkabileceği ve hastanın yaşam kalitesi ve ruhsal durumunun etkilenebileceği akılda tutulmalı ve uygun tedavi ile hastaların bu durumları düzeltilmelidir.

Anahtar Kelimeler: Anksiyete, Depresyon, Hipotiroidi, Hormon regülasyonu, İlaç uyumu, Öfke, Saldırganlık, Yaşam kalitesi. 


\section{Abstract}

Clinical and subclinical hypothyroidism disease is frequently associated with anxiety and depression. This condition also negatively affects the quality of life and mental state of patients. In such cases, there may be improvements in the quality of life and mental state of patients with hormone replacement therapy. The aim of our study is to investigate the effectiveness of hormone regulation in clinical and subclinical hypothyroidism patients on quality of life, mental state, and anger control. A questionnaire consisting of the Hospital Anxiety and Depression scale (HAD), EQ-5D general quality of life scale, drug compliance notification scale, and aggression scale was applied to 82 hypothyroidism patients included in the study. Thyroid function tests (TSH and fT4) of patients were recorded. The questionnaire form was applied to the patients again at least 3 weeks after the treatment was planned for the first control with TSH regulations. The average age of the patients was $40.8 \pm 13.4$ years, $69.5 \%(n=57)$ of participants were women and $57.3 \%(n=47)$ were cases of subclinical hypothyroidism. In the pre-treatment period, there was no significant difference between the patient groups with clinical and subclinical hypothyroidism in terms of mean age, gender, education level and other sociodemographic data. In the clinical hypothyroidism patient group, anxiety symptoms were $40 \%$ and depression symptoms were $37.1 \%$, while in the subclinical hypothyroidism patient group, anxiety symptoms were $31.9 \%$ and depression symptoms were $23.4 \%$. There was a positive relationship between depression levels and TSH, and a low level of negative relationship between fT4. No statistically significant association was found between quality of life and aggression levels and TSH and fT4. A significant decrease in the average scores of anxiety, depression, and aggression levels was found in both groups of patients compared to before and after treatment. Quality of life scale scores were significantly increased after treatment. No significant differences were observed between pre-and post-treatment drug compliance scores of patients in clinical hypothyroidism patients, while significant differences were found in subclinical hypothyroidism group. After hormone replacement therapy, depression and anxiety risks and aggression levels of the patients in both groups decreased and their quality of life increased. Considering the biopsychosocial approach when evaluating the patient's complaints in family medicine practice, it should be kept in mind that psychiatric symptoms are common in clinical and subclinical hypothyroidism, sometimes hypothyroidism may present with psychiatric symptoms, and the patient's quality of life and mental state may be affected, and their conditions should be corrected with appropriate treatment.

Keywords: Aggression, Anger, Anxiety, Depression, Drug compliance, Hormone regulation, Hypothyroidism, Quality of life.

Bu çalışma 16-18 Nisan 2021 tarihinde "6th International Congress of Health Sciences and Family Medicine 2021 İzmir, Türkiye" kongresinde sözlü bildiri olarak sunulmuştur.

\section{Giriş}

Hipotiroidi, dokulardaki tiroid hormon konsantrasyonunun yetersizliği veya işlev bozukluğu sonucu meydana gelen bir hastalıktır. Tiroid bezi ve hormonlarına bağlı rahatsızlıklar arasında en sık karşılaşılan durumlar klinik ve subklinik hipotiroididir. Toplum çalışmalarında aşikar hipotiroidi prevalansı $\% 0.2-0.4$ ve subklinik hipotiroidi prevalansı \%4-8.5 olarak bildirilmektedir [1]. Literatürde, tüm kronik hastalıklarda görüldüğü gibi hipotiroidi hastalarında da psikiyatrik belirtilerin ortaya çıktığı ifade edilmektedir. Subklinik hipotiroidi hastalarında sık görülen nöropsikolojik değişiklikler anksiyete ve depresyon iken, unutkanlık, düşüncede yavaşlama ve konsantrasyon eksikliği gibi yaşam kalitesi ve kognitif fonksiyonlarla ilişkili bozukluklar da görülmektedir [2].

Hipotiroidizm, yaşam kalitesi üzerinde önemli derecede negatif etkilere neden olabilen, fizyolojik ve psikolojik birçok belirti ve semptomları olan, hayat boyu devam eden kronik bir hastalıktır. Hipotiroidi hastalarında sık görülen stres, gerginlik, unutkanlık ve fiziksel işlev bozuklukları yaşam kalitesini kötü yönde etkileyen en önemli bileşenlerdendir [3]. Tiroid hastalıklarının, tiroid fonksiyonunun normale dönmesiyle düzeltilebilecek psikiyatrik bozukluklara neden olabileceği uzun yıllardan beri kabul gören bir görüştür [4]. Hipotiroidizmin belirtileri depresyonu, hipertiroidizmin semptomları ise anksiyete, disfori, duygusal kararsızık ve maniyi 
taklit etmektedir [5,6]. Duygudurum bozukluğu olan hastaların \%1-4'ünde aşikar hipotiroidi, \%440'ında subklinik hipotiroidi saptanmaktadır [4]. Psikiyatrik belirti düzeyi ve bunların tiroid hormon düzeyleriyle ilişkilerini araştırmak için yapılan bir çalışmada, anksiyete seviyelerinin hipotiroidi hastalarında sağlıklı kontrol grubuna kıyasla anlamlı derecede yüksek olduğu gözlemlenmiştir [7]. Hipotiroidi hastalarına tiroid replasman tedavisi uygulandığında ise psikiyatrik semptomlarının gerilediği belirtilmektedir [2].

Aile hekimliği merkezlerine hipotiroidi ve psikiyatrik belirtilerle başvuran hasta sayısı giderek artmaktadır. Aile hekimliğinin temel yaklaşımı olan biyopsikososyal yaklaşım gereği, hastaları çok yönlü nedensellik çerçevesinde biyolojik, sosyolojik ve psikolojik açıdan bir bütün olarak değerlendirmek gerekmektedir. Çalışmamızın amacı klinik ve subklinik hipotiroidi hastalarında hormon regülasyonu ve ilaç uyumunun, yaşam kalitesi, ruhsal durum ve öfke kontrolü üzerine etkinliğini araştırmaktır.

\section{Gereç ve Yöntem}

Araştırmanın etik yönü

Çalışma protokolü için Sağlık Bilimleri Üniversitesi Girişimsel Olmayan Etik Kurulu'nun 10 Aralık 2019 tarihli kurul toplantısında 19/411 karar numarası ve Tıpta Uzmanlık Eğitim Kurulunun 23 Ocak 2020 tarihli toplantısında 2 karar numarası ile onay alınmıştır.

Hastalar ve işlem

Çalışmamızdaki veriler, 15.01.202001.01.2021 tarihleri arasında Sağlık Bilimleri Üniversitesi Gülhane Eğitim ve Araştırma Hastanesi Endokrinoloji ve Metabolizma Hastalıkları Kliniğine ait polikliniğe başvuran 1885 yaş arasındaki hastalara anket yöntemi kullanılarak elde edilmiştir. Çalışmaya katılmayı kabul eden 101 gönüllü hasta çalışmaya alınmıştır. Çalışmaya katılan hastalardan bazıları takibi bırakmaları ya da ikinci anketi uygulamamaları gibi sebeplerle çalışmadan çıkarılmış ve sonuç olarak 35 klinik hipotiroidi ve 47 subklinik hipotiroidi hastası olmak üzere toplamda 82 katılımcı ile çalışma tamamlanmıştır. Çalışmaya katılmayı kabul eden gönüllülere, sosyodemografik özellikler, ilaç uyumu, ruhsal durum ve saldırganlıkla ilgili ölçeklerden (değerlendirme araçlarından) oluşan toplam 72 soruluk bir anket uygulandı. Hastaların biyokimyasal parametrelerinden TSH ve sT4 değerleri hastane kayıtlarından elde edilmiştir. Katılımcılara rutin tedavi planlandıktan en az 3 hafta sonra olmak üzere TSH regülasyonunun sağlandığı ilk kontrollerinde anket formu tekrar uygulanarak, araştırmada kullanılan parametrelerin tedavi öncesi ve sonrası karşılaştırmalı analizi yapılmıştır.

\section{Değerlendirme araçları}

İlaç Uyumunu Bildirim Ölçeği (İUBÖ, Medication Adherence Report Scale; MARS): Bireylerin ilaç uyumunu değerlendirmek için Horne ve Hankins tarafından 2001 yılında geliştirilen bu ölçek jenerik bir ölçek olup hastalık çeşidine göre özelleştirilebilmektedir [8]. Katılımcılardan 5 durumun kendilerinde bulunma derecelerini işaretlemeleri istenmektedir. Ölçek $5=$ asla, $4=$ nadiren, $3=$ bazen, $2=s ı k$ sık ve $1=$ her zaman şeklinde $5^{\prime}$ li Likert tipi soru ile değerlendirilir. Ölçekten alınabilecek puanlar 5 ile 25 arasında değişmektedir. Toplam skorlardaki artış uyumluluğu, düşme ise uyumsuzluğu göstermektedir. Ölçeğin Türkçeye uyarlanması, güvenilirlik ve geçerliliği Temeloğlu Şen ve ark. tarafından yapılmıştır [9].

EQ-5D Genel Yaşam Kalitesi Ölçeği: Kronik hastalığı olan bireylerde yaşam kalitesi genel sağlık ölçekleriyle ve hastalığa özel ölçeklerle değerlendirilebilmektedir. Bu ölçek Batı Avrupa Yaşam Kalitesi Araştırma Topluluğu EuroQol grubu tarafından 1987 yılında geliştirilmiş ve Türkçenin de dahil olduğu altmıştan fazla dile çevrilmiştir [10]. Ölçek iki bölümden oluşmaktadır. Birinci bölüm EQ-5D indeks ölçeğidir ve hareket, öz-bakım, olağan aktiviteler, ağrı/rahatsızlık ve endişe/depresyon olmak üzere 5 ayrı parametreden oluşur. Ölçeğin bu beş parametre üzerinden hesaplanan indeks puanı 0.59 ile 1 arasında değişir. Skor fonksiyonunda 0 değeri ölümü, 1 değeri ise mükemmel sağlığı belirtirken eksi değerler bilincin kapalı olması ve yatağa bağımlı şekilde yaşama gibi olumsuz durumları belirtmektedir. İkinci bölüm EQ-5D VAS (visual analogue scale) ölçeği olup katılımcıların şimdiki sağıı düzeyleri ile ilgili 0 ile 100 arasında 
puan verdikleri ve bunu termometreye benzer bir skala üzerinde belirttikleri bir görsel analog ölçeğidir. Ölçeğin puanı arttıkça sağlık algısı olumlu yönde artmaktadır. Bu ölçek ile 0-100 arasında değişen değerlerde yaşam kalitesi puanları elde edilmektedir. Ölçeğin Türkçe geçerlilik güvenilirlik çalışması 2009 yılında Kahyaoğlu tarafından yüksek lisans tezi olarak "Akut koroner sendromlu hastalarda yaşam kalitesi: EQ-5D ölçeğinin geçerlilik ve güvenirlik çalışması" isimli araştırmayla yapılmıştır [11].

Hastane Anksiyete ve Depresyon (Hospital Anxiety and Depression, HAD) ölçeği: Zigmond ve Snaith tarafından 1983 yılında geliştirilen bu ölçek hastalarda anksiyete ve depresyon riskinin seviyesini ve şiddet değişimini belirlemek için geliştirilmiştir [12]. Fiziksel rahatsızlığı olup sağlık hizmetine başvuran hastalarda anksiyete ve depresyon riskini mümkün olan en kısa zamanda belirlemek için kullanıır, ancak tanı koyma amacıyla kullanılmaz. Ölçek 14 sorudan oluşup; yedisi (çift sayılar) depresyonu ve yedisi (tek sayılar) anksiyeteyi değerlendirmektedir. Cevaplar dörtlü Likert şeklindedir ve puanlama 03 arasındadır. Ölçekte her sorunun puanlaması farklıdır. Katılımcıların alt ölçeklerin her ikisinden alabilecekleri en düşük skor 0 , en büyük skor ise 21 'dir. Ölçeğin kesme noktaları anksiyete alt ölçeği için 10 ve depresyon alt ölçeği için 7 olarak bulunmuştur. Puanları bu değerlerin üzerinde olan bireyler risk altındaki kişiler olarak değerlendirilir. Aydemir ve ark. 1997 yılında ölçeğin güvenilirlik ve geçerlilik çalışmasını yapmışlardır [13].

Saldırganlık Ölçeği: Buss ve Peryy'nin 1992'de geliştirdiği bu ölçek 2000 yılında Buss ve Warren tarafından güncellenmiştir. Saldırganlık ölçeği (aggression questionnaire), saldırganlık davranışının varlığını ve türünü belirlemek amacıyla uygulanır. Ölçek 34 maddeden oluşur; dolaylı saldırganlık ( 6 madde), düşmanlık (8 madde), fiziksel saldırganlık (8 madde), öfke ( 7 madde) ve sözel saldırganlık ( 5 madde) bölümleri olmak üzere 5 alt ölçeği içerir. Değerlendirme, toplam puan ve alt ölçeklerin puanları hesaplanarak yapılabilmektedir. Değerlendirmede toplam puanda en yüksek 170 ve en düşük 34 puan alınabilir. Toplam ölçek puanı $\leq 58$ olduğunda saldırganlık düzeyi düşük, 59-110 olduğunda orta ve $\geq 111$ olduğunda yüksek olarak değerlendirilmektedir [14]. Saldırganlık düzeyleri arttıkça öfke kontrolü azalmaktadır. Ölçeğin Türkiye uyarlaması, Türkçeye çevirisi, geçerlilik ve güvenilirlik çalışması Can (2002) tarafından yapılmıştır [15].

\section{İstatistiksel Analiz}

Verilerin analizi SPSS 22.0 programı ile bilgisayar ortamında yapıldı. Devamlı verilerin analizi için ilk olarak Kolmogrov Smirnov uyum testi ile normal dağılım durumlarına bakıldı. Normal dağılıma uyan veriler için parametrik ve uymayan veriler için nonparametrik testler kullanıldı. Gruplar arası farklııklar değerlendirilirken, nonparametrik testler kullanıldığında bağımlı gruplarda Wilcoxon Signed Ranks testi, bağımlı olmayan gruplarda Mann Whitney $U$ testi ile kullanıldı. Parametrik testler kullanıldığında ise bağımlı gruplarda Paired Sample $T$ testi kullanıldı. Nonparametrik gruplarda değişkenler arasındaki ilişki Spearman korelasyon testleri ile araştırıldı. Nitel verilerin gruplar arası karşılaştırımasında ki-kare testi ve gerekli olduğunda Fischer exact test kullanıldı. Gruplar arasındaki farklıııklar güvenilirlik aralığı \%95 olmak üzere $p<0.05$ değerlerinde anlamlı olarak kabul edildi.

\section{Bulgular}

Katılımcılar klinik hipotiroidi ve subklinik hipotiroidi olmak üzere iki gruptan oluşmaktaydı. Katılımcıların \%57.3'ünü $\quad(n=47)$ subklinik hipotiroidi vakaları oluşturuyordu. Katılımcıların genel yaş ortalaması $40.8 \pm 13.4$ olarak hesaplandı. Hasta grupları incelendiğinde yaş ortalamaları klinik hipotiroidi hastaları için $44 \pm 13.3 \quad(\min =18-m a k s=68)$ ve subklinik hipotiroidi hastaları için $38.3 \pm 13.1 \quad$ ( $\mathrm{min}=18$ maks=67) olarak belirlendi. Klinik ve subklinik düzeyde hipotiroidi saptanan hasta grupları arasında yaş ortalamaları, cinsiyet, eğitim düzeyleri ve diğer sosyodemografik veriler açısından anlamlı farklılık yoktu. Hasta gruplarının sosyodemografik özellikleri Tablo 1'de görülmektedir.

Tedavi öncesi dönemde katılımcıların tamamıma bakıldığında, HAD ölçeğine göre anksiyete skoru 10 üzerinde olan 29 (35.4\%) 
hasta varken, depresyon skoru 10 üzerinde olan hasta sayısı 24 (29.3\%) idi. Hasta gruplarına göre incelendiğinde klinik hipotiroidi hasta grubunun \%40'ında $(n=14)$, subklinik hipotiroidi hasta grubunun ise \%31.9'unda $(n=15)$ anksiyete olduğu görülürken, iki hasta grubu arasında istatistiksel olarak anlamlı bir farklılık yoktu. Klinik hipotiroidi hasta grubunun \%37.1'inde $(n=13)$, subklinik hipotiroidi hasta grubunun ise \%23.4'ünde $(n=11)$ depresyon vardı ve hasta grupları arasında istatistiksel olarak anlamlı bir farklılık yoktu. Hastalar cinsiyete göre incelendiğinde, anksiyete görülme oranı erkeklerde \%16 $(n=4)$ iken kadınlarda \%43.9 $(n=25)$ olarak tespit edildi ve bu farklılık istatistiksel açıdan anlamlıydı. Erkeklerde depresyon görülme oranı \%36 ( $n=9)$, kadınlarda ise \%26.3 $(n=15)$ olarak görüldü ve cinsiyetler arasında depresyon görülme bakımından anlamlı farklılık yoktu (Tablo 2).

Tablo 1. Hasta gruplarının sosyodemografik özelliklerine göre dağılımı.

\begin{tabular}{|c|c|c|c|c|}
\hline \multicolumn{2}{|c|}{ Sosyodemografik veriler } & \multirow{2}{*}{$\begin{array}{l}\text { Klinik hipotiroidi } \\
(n=35)\end{array}$} & \multirow{2}{*}{ 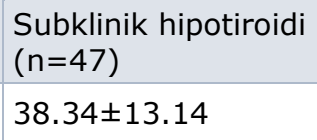 } & \multirow{2}{*}{$\begin{array}{l}\mathrm{p} \\
0.051 * *\end{array}$} \\
\hline Yaş & YIl (standart sapma) & & & \\
\hline \multirow{2}{*}{$\begin{array}{l}\text { Cinsiyet } \\
(\mathrm{n})(\%)\end{array}$} & Erkek & $11(44)$ & $14(56)$ & \multirow{2}{*}{$0.873 *$} \\
\hline & Kadın & $24(42.1)$ & $33(57.9)$ & \\
\hline \multirow{2}{*}{$\begin{array}{l}\text { Medeni durum } \\
(\mathrm{n})(\%)\end{array}$} & Evli & $27(49.1)$ & $28(50.9)$ & \multirow{2}{*}{$0.094 *$} \\
\hline & Bekar & $8(29.6)$ & $19(70.4)$ & \\
\hline \multirow{4}{*}{$\begin{array}{l}\text { Eğitim durumu } \\
(\mathrm{n})(\%)\end{array}$} & Okuryazar değil & $1(20)$ & $4(80)$ & \multirow{4}{*}{$0.226 *$} \\
\hline & İlköğretim & $15(57.7)$ & $11(42.3)$ & \\
\hline & Lise & $8(42.1)$ & $11(57.9)$ & \\
\hline & Yükseköğretim & $11(34.4)$ & $21(65.6)$ & \\
\hline \multirow{3}{*}{$\begin{array}{l}\text { Aylık gelir durumu } \\
(\mathrm{n})(\%)\end{array}$} & Gelir giderden az & $10(45.5)$ & $12(54.5)$ & \multirow{3}{*}{$0.883 *$} \\
\hline & Gelir gidere eşit & $21(42.9)$ & $28(57.1)$ & \\
\hline & Gelir giderden fazla & $4(36.4)$ & $7(63.6)$ & \\
\hline \multirow{3}{*}{$\begin{array}{l}\text { Sürekli yaşadığı yer } \\
(n)(\%)\end{array}$} & Köy-kırsal & $5(62.5)$ & $3(37.5)$ & \multirow{3}{*}{$0.318^{*}$} \\
\hline & İlçe & $9(50)$ & $9(50)$ & \\
\hline & Şehir & $21(37.5)$ & $35(62.5)$ & \\
\hline \multirow{3}{*}{$\begin{array}{l}\text { Aile yapısı } \\
(n)(\%)\end{array}$} & Yalnız yaşıyor & $4(44.4)$ & $5(55.6)$ & \multirow{3}{*}{$0.480 *$} \\
\hline & Çekirdek aile & $25(39.7)$ & $38(60.3)$ & \\
\hline & Geniş aile & $6(60)$ & $4(40)$ & \\
\hline \multirow{2}{*}{$\begin{array}{l}\text { Bakmakla yükümlü olduğu } \\
\text { kişi durumu } \\
\text { (n) }(\%)\end{array}$} & Yok & $33(45.8)$ & $39(54.2)$ & \multirow{2}{*}{$0.124^{a}$} \\
\hline & Var & $2(20)$ & $8(80)$ & \\
\hline
\end{tabular}

Tablo 2. Tedavi öncesinde hastaların anksiyete ve depresyon belirti durumlarının vaka tipi ve cinsiyete göre incelenmesi $(n=82)$.

\begin{tabular}{|c|c|c|c|c|c|c|c|}
\hline \multirow{2}{*}{\multicolumn{2}{|c|}{$\begin{array}{l}\text { HAD alt ölçekleri } \rightarrow \\
\text { Değişkenler }\end{array}$}} & \multicolumn{3}{|c|}{ Anksiyete } & \multicolumn{3}{|c|}{ Depresyon } \\
\hline & & $\begin{array}{c}\text { Var } \\
\mathrm{n}(\%)^{*}\end{array}$ & $\begin{array}{c}\text { Yok } \\
\text { n (\%)* }\end{array}$ & $\mathrm{p} * *$ & $\begin{array}{c}\text { Var } \\
\mathrm{n}(\%)^{*}\end{array}$ & $\begin{array}{c}\text { Yok } \\
\text { n }(\%)^{*}\end{array}$ & $\mathrm{p}^{* *}$ \\
\hline \multirow{2}{*}{ Vaka tipi } & Klinik & $14(40)$ & $21(60)$ & \multirow{2}{*}{0.449} & $13(37.1)$ & $22(62.9)$ & \multirow{2}{*}{0.176} \\
\hline & Subklinik & 15 (31.9) & $32(68.1)$ & & $11(23.4)$ & $36(76.6)$ & \\
\hline \multirow{2}{*}{ Cinsiyet } & Erkek & $4(16)$ & $21(84)$ & \multirow{2}{*}{0.015} & $9(36)$ & $16(64)$ & \multirow{2}{*}{0.375} \\
\hline & Kadın & 25 (43.9) & $32(56.1)$ & & $15(26.3)$ & $42(73.7)$ & \\
\hline
\end{tabular}

HAD: Hastane anksiyete ve depresyon. **Pearson ki-kare. *Sütun yüzdesi. 
Klinik hipotiroidi hasta grubunda anksiyete ve depresyon ölçeği ortalama skorlarının tedavi sonrasında istatistiksel olarak anlamlı düzeyde düştüğü görüldü. Aynı hasta grubunda yaşam kalitesi ölçeği indeks ortalama skoru ve VAS ortalama skoru anlamlı düzeyde artış gösterdi. Hastaların ilaç uyumu ölçeği inceliğinde tedavi öncesi ve sonrası dönemde anlamlı bir farklılık görülmedi. Saldırganlık ölçeği alt gruplarına bakıldığında sözel, öfke, düşmanlık ve dolaylı ölçek skor ortalamalarında tedavi sonrası değerler tedavi öncesine göre istatistiksel olarak anlamlı bir düşüş gösterirken fiziksel ölçek skorundaki düşüş anlamlı değildi (Tablo 3).

Tablo 3. Klinik hipotiroidi olan hastalarda anksiyete ve depresyon belirtisi, yaşam kalitesi, saldırganlık durumu, ilaç uyum düzeylerinin tedavi öncesi ve tedavi sonrası dönemler için karşılaştırılması.

\begin{tabular}{|c|c|c|c|c|c|c|}
\hline \multirow[b]{2}{*}{ Ölçekler } & \multirow[b]{2}{*}{$\mathrm{n}$} & \multicolumn{2}{|c|}{ Tedavi öncesi } & \multicolumn{2}{|c|}{ Tedavi sonrası } & \multirow[b]{2}{*}{$\mathrm{p}$} \\
\hline & & Ort $\pm S S$ & Min-maks & Ort $\pm S S$ & Min-maks & \\
\hline HAD-Anksiyete & 35 & $8.40 \pm 4.51$ & $0-17$ & $6.17 \pm 3.63$ & $0-14$ & $<0.001^{a}$ \\
\hline HAD-Depresyon & 35 & $8.69 \pm 4.95$ & $0-20$ & $5.60 \pm 3.92$ & $0-15$ & $<0.001^{a}$ \\
\hline$E Q-5 D$ indeks & 35 & $0.754 \pm 0.12$ & 0.587-0.919 & $0.826 \pm 0.09$ & 0.597-0.919 & $<0.001^{b}$ \\
\hline EQ-5D VAS & 35 & $68.00 \pm 12.55$ & $40-90$ & $75.14 \pm 12.21$ & $50-100$ & $<0.001^{b}$ \\
\hline İlaç uyumu & 35 & $21.17 \pm 3.46$ & $11-25$ & $21.29 \pm 3.64$ & $15-25$ & $0.764^{b}$ \\
\hline Fiziksel SÖ & 35 & $12.37 \pm 4.10$ & $8-22$ & $11.49 \pm 3.59$ & $8-22$ & $0.083^{b}$ \\
\hline Sözel SÖ & 35 & $12.46 \pm 2.93$ & $7-19$ & $11.49 \pm 2.67$ & $7-18$ & $0.007^{a}$ \\
\hline Öfke SÖ & 35 & $19.26 \pm 6.68$ & $9-35$ & $15.46 \pm 4.11$ & $9-27$ & $<0.001^{a}$ \\
\hline Düşmanlık SÖ & 35 & $16.11 \pm 5.33$ & $7-29$ & $12.80 \pm 3.83$ & $7-24$ & $<0.001^{a}$ \\
\hline Dolaylı SÖ & 35 & $10.66 \pm 3.00$ & $6-17$ & $9.94 \pm 2.70$ & $6-17$ & $0.039^{b}$ \\
\hline
\end{tabular}

EQ-5D: Genel yaşam kalitesi ölçeği. HAD: Hastane anksiyete ve depresyon ölçeği. SÖ: Saldırganlık ölçeği. VAS: Görsel analog ölçeği. Ort: Ortalama. SS: Standart sapma. Min: Minimum. Maks: Maksimum. aPaired Samples Test. bWilcoxon Test.

Tablo 4. Subklinik hipotiroidi olan hastalarda anksiyete ve depresyon belirtisi, yaşam kalitesi, saldırganlık durumu, ilaç uyum düzeylerinin tedavi öncesi ve tedavi sonrası dönemler için karşılaştırılması.

\begin{tabular}{|c|c|c|c|c|c|c|}
\hline \multirow[b]{2}{*}{ Ölçekler } & \multirow[b]{2}{*}{$\mathrm{n}$} & \multicolumn{2}{|c|}{ Tedavi öncesi } & \multicolumn{2}{|c|}{ Tedavi sonrası } & \multirow[b]{2}{*}{$\mathrm{p}$} \\
\hline & & Ort $\pm S S$ & Min-maks & Ort $\pm S S$ & Min-maks & \\
\hline HAD-Anksiyete & 47 & $7.36 \pm 4.22$ & $1-19$ & $4.81 \pm 3.44$ & $0-17$ & $<0.001^{a}$ \\
\hline HAD-Depresyon & 47 & $5.91 \pm 4.45$ & $0-18$ & $3.15 \pm 2.54$ & $0-10$ & $<0.001^{a}$ \\
\hline$E Q-5 D$ indeks & 47 & $0.772 \pm 0.15$ & $0.105-0.919$ & $0.802 \pm 0.15$ & $0.082-0.919$ & $0.018^{\mathrm{b}}$ \\
\hline EQ-5D VAS & 47 & $73.61 \pm 17.18$ & $30-100$ & $80.00 \pm 14.92$ & $50-100$ & $<0.001^{b}$ \\
\hline İlaç uyumu & 47 & $21.45 \pm 3.14$ & $13-25$ & $22.13 \pm 3.32$ & $15-25$ & $0.019^{b}$ \\
\hline Fiziksel SÖ & 47 & $12.38 \pm 3.96$ & $8-23$ & $11.30 \pm 3.14$ & $8-22$ & $0.006^{\mathrm{b}}$ \\
\hline Sözel SÖ & 47 & $11.91 \pm 3.45$ & $5-18$ & $10.66 \pm 2.40$ & $5-15$ & $0.003^{a}$ \\
\hline Öfke SÖ & 47 & $16.34 \pm 5.10$ & $8-28$ & $13.55 \pm 3.40$ & $9-22$ & $<0.001^{a}$ \\
\hline Düşmanlık SÖ & 47 & $14.32 \pm 4.11$ & $8-25$ & $12.13 \pm 3.20$ & $7-23$ & $<0.001^{a}$ \\
\hline Dolaylı SÖ & 47 & $11.34 \pm 3.58$ & $7-25$ & $10.36 \pm 2.51$ & $6-17$ & $0.010^{\mathrm{b}}$ \\
\hline
\end{tabular}

Subklinik hipotiroidi hasta grubunda anksiyete ve depresyon ölçeği ortalama skorlarının tedavi sonrasında istatistiksel olarak anlamlı düzeyde düştüğü görüldü. Yaşam kalitesi ölçeği indeks ortalama skoru ve VAS ortalama skoru ise anlamlı düzeyde artış gösterdi. 
Hastaların ilaç uyum ölçeği skorunda tedavi sonrasında tedavi öncesine göre istatistiksel olarak anlamlı derecede artış görüldü. Saldırganlık ölçeği alt gruplarına bakıldığında fiziksel, sözel, öfke, düşmanlık ve dolaylı ölçek skor ortalamalarında tedavi sonrası dönemde tedavi öncesine göre istatistiksel olarak anlamlı bir düşüş görüldü (Tablo 4).

Katılımcıların tedavi öncesinde TSH, sT4, yaş ve ilaç uyum değerleri ile anksiyete ve depresyon belirtisi, yaşam kalitesi ve saldırganlık düzeyleri arasındaki ilişki incelendiğinde, TSH değerleri ile depresyon skoru arasında düşük düzeyde pozitif yönde, sT4 düzeyi ile depresyon arasında ise negatif yönde istatistiksel olarak anlamlı bir ilişki saptanırken, diğer ölçek skorları arasında anlamlı bir ilişki görülmedi. Yaş ile anksiyete ve depresyon arasında pozitif yönde, yaşam kalitesi arasında ise negatif yönde orta düzeyde istatistiksel olarak anlamlı bir ilişki saptandı. Hastaların ilaç uyumu ile anksiyete, depresyon, öfke, fiziksel, düşmanlık ve dolaylı saldırganlık ölçeği skorları arasında negatif yönde istatistiksel olarak anlamlı bir ilişki görüldü. Katılımcıların ilaç uyumu ile yaşam kaliteleri arasında ise pozitif yönde orta düzeyde istatistiksel olarak anlamlı ilişki bulundu (Tablo 5).

Tablo 5. Tedavi öncesi hastaların TSH, sT4, yaş ve ilaç uyumu ile anksiyete ve depresyon belirtisi, yaşam kalitesi ve saldırganlık ölçeği alt grupları ilişkilerinin incelenmesi $(n=82)$.

\begin{tabular}{|c|c|c|c|c|c|c|c|c|}
\hline \multirow[b]{2}{*}{ Ölçekler } & \multicolumn{2}{|c|}{ TSH } & \multicolumn{2}{|c|}{ sT4 } & \multicolumn{2}{|c|}{ Yaş } & \multicolumn{2}{|c|}{ İlaç uyumu } \\
\hline & $r$ & $p^{a}$ & $r$ & $p^{a}$ & $r$ & $p^{a}$ & $r$ & $\mathrm{p}^{\mathrm{a}}$ \\
\hline HAD-Anksiyete & 0.026 & 0820 & -0.105 & 0.346 & $0.334 * *$ & 0.002 & $-0.369 * *$ & 0.001 \\
\hline HAD-Depresyon & $0.218^{*}$ & 0.050 & $-0.250 *$ & 0.023 & $0.357 * *$ & 0.001 & $-0.425 * *$ & 0.001 \\
\hline EQ-5D indeks & -0.096 & 0.389 & 0.162 & 0.147 & $-0.455 * *$ & $<0.001$ & $0.313^{* *}$ & 0.004 \\
\hline EQ-5D VAS & -0.199 & 0.073 & 0.142 & 0.203 & $-0.443 * *$ & $<0.001$ & $0.436 * *$ & $<0.001$ \\
\hline Fiziksel SÖ & 0.090 & 0.422 & -0.009 & 0.933 & -0.041 & 0.715 & $-0.335 * *$ & 0.002 \\
\hline Sözel SÖ & -0.009 & 0.934 & -0.019 & 0.866 & -0.055 & 0.625 & -0.103 & 0.358 \\
\hline Öfke SÖ & 0.073 & 0.517 & -0.169 & 0.129 & 0.134 & 0.230 & $-0.255^{*}$ & 0.021 \\
\hline Düşmanlık SÖ & 0.035 & 0.755 & -0.086 & 0.443 & 0.139 & 0.214 & $-0.360 * *$ & 0.001 \\
\hline Dolaylı SÖ & -0.089 & 0.425 & 0.037 & 0.738 & 0.013 & 0.906 & $-0.298 * *$ & 0.007 \\
\hline
\end{tabular}

HAD: Hastane anksiyete ve depresyon ölçeği. EQ-5D: Genel yaşam kalitesi ölçeği. VAS: Görsel analog Ölçeği. SÖ: Saldırganlık ölçeği. TSH: Tiroid uyarıcı hormon. sT4:Serbest tiroksin. aSpearman korelasyon testi. r: Spearman korelasyon katsayısı. ${ }^{* *} p<0.01$ İstatistiksel anlamlılık düzeyi. $* p<0.05$ İstatistiksel anlamlılık düzeyi.

\section{Tartışma}

Çalışmamızda araştırmamıza katılan klinik ve subklinik hipotiroidi hastalarında sosyodemografik özellikler, anksiyete ve depresyon durumu, yaşam kalitesi, ilaç uyumu ve öfke kontrol durumlarının tedavi öncesi ve sonrası dönemlerdeki durumları karşılaştırılarak incelendi. Hasta grupları arasında sosyodemografik veriler bakımından anlamlı bir farklılık yoktu. Hasta gruplarının her ikisinde de tedavi öncesi ve sonrası dönem karşılaştırıldığında anksiyete, depresyon ve saldırganlık düzeyi ortalama skorlarında tedavi sonrasında anlamlı bir düşüş saptandı. Yaşam kalitesi ölçek ortalama skorlarında ise tedavi sonrasında anlamlı düzeyde bir artış olduğu görüldü. Klinik hipotiroidi hasta grubunda hastaların ilaç uyum skorlarında tedavi öncesi ve sonrası arasında anlamlı bir farklılık görülmezken, subklinik hipotiroidi hastalarında hastaların ilaç uyumu ile anksiyete, depresyon, öfke, fiziksel, düşmanlık ve dolaylı saldırganlık ölçeği skorları arasında negatif yönde, yaşam kaliteleri arasında ise pozitif yönde orta düzeyde istatistiksel olarak anlamlı bir ilişki olduğu bulundu. Kronik hipotiroidi ile psikiyatrik belirtilerin birlikteliğinin araştırıldığı çalışmalarda yaşla birlikte hipotirodi sıklığının arttığı ve bilişsel fonksiyonlarda azalma olduğuna dikkat çekilmiştir [16]. Engum ve ark.'nın 4300 hasta üzerinde yaptığı bir araştırmada tiroid fonksiyonları ile depresyon ve anksiyete bozukluğu arasındaki ilişki incelenmiş ve hipotiroidi saptanan hastaların büyük çoğunluğunu orta yaş kadın hastaların oluşturduğu bildirilmiştir [17]. Gülseren ve 
ark.'nın 2006 yılında yaptıkları aşikar ve subklinik tiroid işlev bozukluğu olan 160 hastanın dahil edildiği bir çalışmada orta yaş hasta grubunun daha yüksek oranda olduğu görülmüştür [18]. Bizim çalışmamızda da hastaların yaş ortalaması literatürle uyumlu olarak klinik hipotiroidi hasta grubunda 44 ve subklinik hipotiroidi hasta grubunda 38.3 olarak bulundu. Literatür incelendiğinde, yaşılılarda tiroid hipofonksiyonu veya subklinik hipotiroidi prevalansının orta yaş ve gençlere göre daha yüksek olduğu görülmektedir [16]. Tiroid hormon konsantrasyonları yaşla birlikte değiştiği ve yaşlanmaya bilişsel azalma eşlik ettiği için, tiroid fonksiyonlarındaki fizyolojik değişikliklerin normal yaşlanma sırasındaki bilişsel değişikliklere neden olabileceği de bildirilmiştir [19]. Yaşlılarda tiroid hipofonksiyonu daha yüksek olmasına rağmen katılımcıların orta yaş ağırlıklı olmasının sebebi çalışmamıza uyumun genç katılımcılarda daha yüksek oranda olmasından kaynaklı olabilir. Yaş ile hastaların ruhsal durumu, yaşam kalitesi ve öfke kontrolleri arasındaki ilişkiye baktığımızda, depresyon ve anksiyete ile pozitif yönde orta düzeyde anlamlı bir ilişki olduğunu gördük. Yaş ile yaşam kalitesi arasında ise negatif yönde orta düzeyde anlamlı bir ilişki bulunurken, hastaların yaşı ile öfke düzeyleri arasında anlamlı bir ilişki görülmedi.

Klinik ve subklinik hipotiroidi hastalarında görülen psikiyatrik belirtilerin araştırıldığı çalışmalarda, tiroid işlev bozukluklarında duygudurum ve anksiyete belirtileri başta olmak üzere psikiyatrik belirtilerin sık görüldüğü bildirilmektedir [20-22]. Haggerty ve ark. hipotiroidi hastalarında yaşamları boyunca depresyon görülme oranını \%56 olarak bildirmişlerdir [23]. Önceki birçok çalışmada tiroid fonksiyon yetersizliği olan hastalarda depresyon ve diğer psikiyatrik bozuklukların görülme sıklığının arttığı yönünde bildirimler olmasına rağmen, subklinik hipotiroidi hastalarında kontrol grubuna göre farklılık gözlemlenmediğini bildiren çalışmalar da vardır $[17,24]$. Eren ve ark. psikiyatrik belirtiler ile tiroid hormon düzeyleri arasındaki ilişkiyi inceledikleri 2006 tarihli çalışmalarında hipotiroidi grubunda $(n=40)$ anksiyete düzeylerinin subklinik hipotiroidi grubu $(n=40)$ ve sağlıklı kontrol grubuna $(n=45)$ oranla anlamlı derecede yüksek olduğunu, subklinik hipotiroidi hastalarının anksiyete düzeylerinin de ötiroid kontrol grubuna göre anlamlı derecede yüksek olduğunu bulmuşlardır [7]. Bizim çalışmamızda da literatüre benzer şekilde klinik hipotiroidi hasta grubunda anksiyete oranı \%40 ve depresyon sıklığı \%37.1 olarak bulunurken, subklinik hipotiroidi hasta grubunda anksiyete oranı \%31.9 ve depresyon oranı \%23.4 olarak bulundu. Son zamanlarda yapılan çalışmalarda hipotiroidi hastalarında psikiyatrik belirtilerin bildirilme sıklığındaki artışın tanı olanaklarının artması ve ayrıca psikiyatrik belirtilere karşı daha duyarlı olunması gibi yeni değişkenler ile ilişkili olabileceği düşünülebilir.

Tiroid patolojileri ile birlikte görülen depresyon ve anksiyete bozukluğu varlığında hem endokrinolojik hem de psikiyatrik yönden tedavi uyumu bozulmakta, tedavi süresi uzamakta ve hastaların yaşam kalitesi olumsuz etkilenmektedir [25]. Araştırmamızda biz de ilaç uyumu ile katılımcıların anksiyete, depresyon ve saldırganlık düzeyleri arasında ilişki olup olmadığını incelemek istedik. Tedavi öncesi dönemde hastaların anksiyete, depresyon ve saldırganlık düzeyleri ile ilaç uyumları arasında negatif yönde orta düzeyde anlamlı bir ilişki bulduk. Yaşam kalite düzeyleri ile ilaç uyumu arasında ise pozitif yönde orta düzeyde anlamlı bir ilişki bulduk. Hastaların tedaviye uyumlarının beklediğimiz gibi yaşam kalitelerini ve psikolojik durumlarını önemli derecede etkilediği görüldü.

Tiroid işlev bozukluklarında tedavi ile birlikte hastaların psikiyatrik belirtilerinde düzelmeler olduğu daha önce yapılan araştırmalarda gösterilmiştir. Bauer ve ark.'nın yaptığı bir araştırmada hipotiroidisi olan hastalarda sağlıklı kontrol grubuna göre depresyon ve anksiyete görülme oranı anlamlı derecede yüksek bulunmuş ve tiroid replasman tedavisi sonrası ruhsal bozukluklarda azalma olduğu görülmüştür [26]. Denicoff ve ark.'nın total tiroidektomili hastalar üzerinde yaptıkları ve anksiyete düzeylerinin incelendiği çalışmalarında, tiroid hormon replasmanı durdurulduğunda hastaların anksiyete düzeylerinde artma meydana geldiği gösterilmiştir [27]. Bu durum hipotiroidi hastalarında hormon replasman tedavisi ile hastaların anksiyete ve depresyon gibi psikiyatrik belirtilerinde gerileme 
sağlanabileceği görüşünü doğurmaktadır. Araştırmamızda vardığımız sonuç, bu görüşü destekler şekilde her iki hasta grubunda da tedavi sonrasında HAD ölçeği anksiyete ve depresyon skorlarında anlamlı düşüş olduğu şeklindeydi.

Literatürde tiroid işlev bozukluğu olan hastalarda tedavi sonrasında hastaların yaşam kalitelerinde artış olduğunu belirten birçok çalışma vardır. Gülseren ve ark. tedavi ile ötiroidizmin sağlanması sonrası hastaların yaşam kalitelerinde düzelme olduğunu bulmuş, aşikar tiroid işlev bozukluğu olanlarda, subklinik düzeyde işlev bozukluğu olanlara kıyasla daha fazla gelişme olduğunu göstermişlerdir [18]. Reuters ve ark. 61 subklinik hipotiroidili bireyi tedavi ve plasebo grubu olmak üzere ikiye ayırmış, hormon replasman tedavisi öncesi ve sonrası bireylerin yaşam kalitelerini değerlendirmiştir [28]. Tedavi sonrası hastaların genel sağlık, ağrı ve fiziksel rol alanlarında artış görülürken, canlılık ve fiziksel fonksiyon alanlarında gelişme görülmemiştir [28]. $\mathrm{Bu}$ durum da hormon replasman tedavisine rağmen yaşam kalitesinde etkilenmelerin devam edebileceğini akla getirmektedir. Hipotiroidi hastalarında hormon replasman tedavisine rağmen yaşam kalitesinin uzun süreli değerlendirilmesinde yaşam kalitesinde bozulma görülme sıklığı \%62 olarak bulunurken, hastaların günlük aktivitelerinde $\% 49$ ile $\% 73$ arasında değişen oranlarda daralma olduğu saptanmıştır [29]. Hastaların tedavi sürecinde semptomların devam etmesi nedeniyle her hastanın replasman tedavisinden tatmin olmadığına dair sistematik araştırmalar da mevcuttur $[30,31]$. Çalışmamızda hastaların tamamının tedavi öncesi ve sonrası EQ5D yaşam kalitesi ölçeği ortalama skorları karşılaştırıldığında, tedavi sonrasında hastaların yaşam kalitesi ortalama skorlarında anlamlı bir artış olduğu görüldü. Bu nedenle, semptomların uygun yönetimine yardımcı olması açısından hipotiroidili hastalarda yaşam kalitesi ve hastalık semptomların birlikte değerlendirilmesi önemlidir.

Literatürde hipotiroidizm ve saldırganlık arasındaki ilişkiyi inceleyen az sayıda çalışma vardır. Hipotiroidizmin saldırganlık üzerindeki etkisi ile ilgili önceki araştırmalar genel olarak hayvanlar üzerinde yürütülmüştür. Beaver ve Haug köpekler üzerinde yürüttükleri bir çalışmada, köpeklerde hipotiroidi hastalığına bağlı saldırganlık geliştiğini göstermişleridir [32]. Karşılaştırmalı bir araştırmada hipotiroidizm ile saldırganlık arasında erkekler ve kadınlar için düşük düzeyde pozitif bir ilişkiye işaret edilmiştir [33]. Yontar ve ark.'nın hazırladığı bir vaka sunumunda, total tiroidektomi sonrası tiroid replasman tedavisine uymama ile ilişkili olarak hipotiroidi ve eş zamanlı olarak saldırgan ve manik belirtiler gösteren, tiroid hormonu yerine koyma tedavisi ve antipsikotik tedaviyle hızlı ve etkin biçimde düzelen bir vakadan bahsedilmiştir [34]. Bizim çalışmamızda da her iki hasta grubunda tedavi sonrasında saldırganlık düzeylerinde anlamlı düşüşler görülmesine rağmen, TSH ve sT4 düzeyleri ile saldırganlık düzeyi arasında anlamlı bir ilişki görülmedi.

Çalışmamızda ortaya çıkan tiroid patolojisinin şiddeti ile psikiyatrik belirtiler arasında ilişki olup olmadığına da baktık. Bu konudaki literatürler incelendiğinde; Trzepacz ve ark. bir çalışmalarında, serum tiroid hormonunun yüksekliği ile ilişkili olan periferik endokrinolojik semptomların anksiyete düzeyi ile bağlantılı olduğunu belirtmişlerdir [35]. Ancak aynı yazarın dahil olduğu bir başka çalışmada araştırmacılar tiroid hormon düzeyi ile anksiyete ve depresyon derecesi arasında bir ilişki bulamadıklarını belirtmişleridir [36]. Bizim çalışmamamızda hem klinik hem de subklinik düzeyde hipotiroidisi olan hastalarda, ST4 ve TSH düzeyleri ile anksiyete düzeyleri arasında anlamlı bir ilişki bulunamadı. Hastaların depresyon düzeyleri ile TSH arasında pozitif yönde, ST4 ile de negatif yönde düşük düzeyde anlamlı bir ilişki bulundu. Katılımcıların TSH ve sT4 düzeyleri ile yaşam kalitesi ve saldırganlık düzeyleri arasında anlamlı bir ilişki bulunamadı. Tiroid işlev bozuklukları ve psikiyatrik belirtiler arasındaki ilişkiye dair bir diğer görüş de tiroid hastalıklarının psikiyatrik rahatsızlıklara yatkınlık sağladığı şeklindedir. Tiroid bozukluklarında hormon düzeyleri ile psikiyatrik semptom şiddetleri arasında doğrudan anlamlı bir ilişkinin olmaması tiroid bozukluklarının psikiyatrik hastalık gelişimi için yatkınlık sağladığı görüşünü desteklemektedir.

Çalışmamızın kendi içerisinde kısıtlılıkları mevcuttur. Aile hekimliği temel olarak birinci basamakta hizmet veren bir birim olmasına karşın çalışma örneklemimiz üçüncü basamak poliklinik 
hastalarından oluşmaktaydı. Bu nedenle çalışma sonuçlarımızı aile hekimliği birimlerine başvuran tüm hipotiroidi hastalarına genelleyemeyiz. Veri toplama döneminin, 2019 koronavirus pandemi süreci ile eşzamanlı olması nedeniyle polikliniğe başvuran hasta sayısının ve gönüllü katılımcı sayısının az olması ve hasta takibinde yaşanan zorluklar toplam katılımc sayısını olumsuz olarak etkilemiştir. Ayrıca çalışmamıza dahil olan katılımcıların genel olarak takip ve tedavileri düzenli hastalardan oluşması ve takibi bırakan hastaların çalışmadan çıkarılması da araştırma sonuçlarını etkilemiş olabilir. Bu kısıtlamaların çalışma sonuçları üzerine olumsuz etkilerini minimalize etmek için olgu sayısının daha fazla, takip süresinin daha uzun olduğu ve kontrol grubu olan daha geniş kapsamlı çalışmalara ihtiyaç vardır.

\section{Sonuç}

Çalışma verilerimiz klinik ve subklinik hipotiroidi hastalarında anksiyete bozuklukları veya depresyonun tiroid hastalıkları ile sık birliktelik gösteren ek problemler olduğunu göstermektedir. Bu durum hastaların yaşam kalitelerini ve saldırganlık durumlarını olumsuz olarak etkilemektedir. Bu etkinin şiddeti genel olarak hastaların hormon düzeylerinden bağımsızdı, bununla beraber tedavi sonrasında bu parametrelerin genelinde olumlu yönde düzelmeler olduğunu gördük. Hastaların iyileşmelerinde ise tedaviye uyum ve düzenin önemli oluğunu gözlemledik. Aile hekimliği pratiğinde hasta şikayetlerini değerlendirirken biyopsikososyal yaklaşım göz önünde bulundurularak, klinik ve subklinik hipotiroidide psikiyatrik belirtilerin sık görüldüğü, bazen hipotiroidinin psikiyatrik belirtilerle ortaya çıkabileceği, hastanın yaşam kalitesi ve ruhsal durumunu etkileyebileceği akılda tutulmalıdır. Böylece yanlış tanı ve tedavilerin önüne geçilerek maddi ve manevi kazanımlar sağlanabilir.

Çıkar beyanı: Yazarlar çıkar çatışması bildirmemiştir. Makalenin içeriğinden ve yazılmasından tek başına yazarlar sorumludur. Finansal destek: Bu çalışmaya finansal destek verilmemiştir.

\section{Kaynaklar}

1. Sheehan MT. Biochemical Testing of the Thyroid: TSH is the Best and, Oftentimes, Only Test Needed - A Review for Primary Care. Clin Med Res 2016; 14(2): 83-92. [Crossref] [PubMed]

2. Yarpuz YM, Aydoğan Ü, Sarı O, Aydoğdu A, Üçkaya G, Fenercioğlu A, et al. Subklinik Hipotiroidili Hastalarda Tiroid Replasman Tedavisinin Anksiyete ve Depresyon Düzeylerine Etkisi. Klinik Psikiyatri 2009; 12: 180-7.

3. Walsh JP, Ward LC, Burke V, Bhagat CI, Shiels L, Henley $D$, et al. Small changes in thyroxine dosage do not produce measurable changes in hypothyroid symptoms, well-being, or quality of life: results of a double-blind, randomized clinical trial. J Clin Endocrinol Metab 2006; 91(7): 2624-30. [Crossref] [PubMed]

4. Hage MP, Azar ST. The Link between Thyroid Function and Depression. J Thyroid Res 2012; 2012: 590648. [Crossref] [PubMed]

5. Feldman AZ, Shrestha RT, Hennessey JV. Neuropsychiatric manifestations of thyroid disease. Endocrinol Metab Clin North Am 2013; 42(3): 453-76. [Crossref] [PubMed]

6. Davis JD, Tremont G. Neuropsychiatric aspects of hypothyroidism and treatment reversibility. Minerva Endocrinol 2007; 32(1): 49-65. [PubMed]

7. Eren İ, Cüre E, İnanlı İÇ, Kutlucan A, Köroğlu BK, Tamer MN. Klinik ve subklinik hipotiroidide psikiyatrik belirti düzeyi ve psikiyatrik belirtilerin tiroid hormon düzeyleri ile ilişkisi. Klinik Psikiyatri 2006; 9: 131-7.
8. Horne R, Hankins M. The Medication Adherence report Scale (MARS), 2001. [Database record]. APA PsycTests. [Crossref]

9. Şen ET, Berk ÖS, Sindel D. İlaç uyumunu bildirim ölçeği'nin Türkçe uyarlamasının geçerlik ve güvenirlik çalışması. İstanbul Tıp Fakültesi Dergisi 2019; 82(1): 5261. [Crossref]

10. Rabin $R$, de Charro F. EQ-SD: a measure of health status from the EuroQol Group. Annals of Medicine 2001; 33(5): 337-43. [Crossref]

11. Kahyaoğlu H. Akut koroner sendromlu hastalarda yaşam kalitesi: EQ-5D ölçeğinin Türkçe formunun geçerlilik ve güvenirlik çalışması. Trakya Üniversitesi Sağlık Bilimleri Enstitüsü Hemşirelik Anabilim Dalı, İç Hastalıkları Hemşireliği Yüksek Lisans Programı. Yüksek Lisans Tezi, Edirne, 2009.

12. Zigmond AS, Snaith RP. The hospital anxiety and depression scale. Acta Psychiatr Scand 1983; 67(6): 36170. [Crossref] [PubMed]

13. Aydemir Ö. Hastane Anksiyete ve Depresyon Ölçeği Türkçe formunun geçerlilik ve güvenilirliği. Türk Psikiyatri Dergisi 1997; 8(4): 280-7.

14. Can Gürkan Ö. Nursing Students' Tendency to Aggression and Relevant Factors. Journal of Psychiatric Nursing 2016; 7(2): 87-93. [Crossref]

15. Can S. "Aggression questionnaire" Adlı Ölçeğin Türk Popülasyonunda Geçerlilik ve Güvenilirlik Çalışması. Gülhane Askeri Tıp Akademisi Haydarpaşa Eğitim 
Hastanesi, Ruh Sağlığı ve Hastalıkları Servisi. Uzmanlık Tezi, İstanbul, 2002.

16. Leng $O$, Razvi S. Hypothyroidism in the older population. Thyroid Res 2019; 12: 2. [Crossref] [PubMed]

17. Engum A, Bjøro T, Mykletun A, Dahl AA. An association between depression, anxiety and thyroid function--a clinical fact or an artefact? Acta Psychiatr Scand 2002; 106(1): 2734. [Crossref] [PubMed]

18. Gulseren $S$, Gulseren $L$, Hekimsoy $Z$, Cetinay $P$, Ozen C, Tokatlioglu B. Depression, anxiety, health-related quality of life, and disability in patients with overt and subclinical thyroid dysfunction. Arch Med Res 2006; 37(1): 133-9. [Crossref] [PubMed]

19. Bégin ME, Langlois MF, Lorrain $D$, Cunnane SC. Thyroid Function and Cognition during Aging. Curr Gerontol Geriatr Res 2008; 2008: 474868. [Crossref] [PubMed]

20. Monzani F, Del Guerra $P$, Caraccio N, Pruneti CA, Pucci $E$, Luisi $M$, et al. Subclinical hypothyroidism: neurobehavioral features and beneficial effect of Lthyroxine treatment. Clin Investig 1993; 71(5): 367-71. [Crossref] [PubMed]

21. Szabadi E. Thyroid dysfunction and affective illness. BMJ 1991; 302(6782): 923-4. [Crossref] [PubMed]

22. Whybrow PC, Prange AJ Jr, Treadway CR. Mental changes accompanying thyroid gland dysfunction. A reappraisal using objective psychological measurement. Arch Gen Psychiatry 1969; 20(1): 48-63. [Crossref] [PubMed]

23. Haggerty JJ Jr, Stern RA, Mason GA, Beckwith J, Morey CE, Prange AJ Jr. Subclinical hypothyroidism: a modifiable risk factor for depression? Am J Psychiatry 1993; 150(3): 508-10. [Crossref] [PubMed]

24. Grabe HJ, Völzke H, Lüdemann J, Wolff B, Schwahn C, John $U$, et al. Mental and physical complaints in thyroid disorders in the general population. Acta Psychiatr Scand 2005; 112(4): 286-93. [Crossref] [PubMed]

25. Ozkan S. Psikiyatrik tip: konsültasyon-liyazon psikiyatri. Bull Clin Psychopharmacol 1990; 1(1): 10-7.

26. Bauer M, Szuba MP, Whybrow PC. Psychiatric and behavioral manifestations of hyperthyroidism and hypothyroidism. In: Wolkowitz OM, Rothschild AJ (eds), Psychoneuroendocrinology: The scientific basis of clinical practice. 2003, American Psychiatric Publishing Inc., Arlington, Virginia. pp:419-44.
27. Denicoff KD, Joffe RT, Lakshmanan MC, Robbins J, Rubinow DR. Neuropsychiatric manifestations of altered thyroid state. Am J Psychiatry 1990; 147(1): 94-9. [Crossref] [PubMed]

28. Reuters VS, Almeida Cde $P$, Teixeira Pde F, Vigário Pdos $\mathrm{S}$, Ferreira $\mathrm{MM}$, Castro $\mathrm{CL}$, et al. Effects of subclinical hypothyroidism treatment on psychiatric symptoms, muscular complaints, and quality of life. Arq Bras Endocrinol Metabol 2012; 56(2): 128-36. [Crossref] [PubMed]

29. Watt $T$, Groenvold $M$, Rasmussen AK, Bonnema SJ, Hegedüs $L$, Bjorner JB, et al. Quality of life in patients with benign thyroid disorders. A review. Eur J Endocrinol 2006; 154(4): 501-10. [Crossref] [PubMed]

30. Saravanan $P$, Chau WF, Roberts $N$, Vedhara $K$, Greenwood R, Dayan CM. Psychological well-being in patients on 'adequate' doses of I-thyroxine: results of a large, controlled community-based questionnaire study. Clin Endocrinol (Oxf) 2002; 57(5): 577-85. [Crossref] [PubMed]

31. Kaplan MM, Sarne $D H$, Schneider AB. In search of the impossible dream? Thyroid hormone replacement therapy that treats all symptoms in all hypothyroid patients. J Clin Endocrinol Metab 2003; 88(10): 4540-2. [Crossref] [PubMed]

32. Beaver BV, Haug LI. Canine behaviors associated with hypothyroidism. J Am Anim Hosp Assoc 2003; 39(5): 4314. [Crossref] [PubMed]

33. Ola M. Hypothyroidism and its Impact on General Mental Health, Body Image Satisfaction and Aggression in Males and Females: A Comparative Study. International Journal of Multidisciplinary Current Research 2016; 4(1): 487-9.

34. Yontar G, Semiz M, Kuğu N, Doğan O, Kavakcı Ö. Hipotiroidi ile İlişkili Psikotik Mani: Bir Vaka Sunumu. Journal of Mood Disorders 2015; 5(3): 134-7. [Crossref]

35. Trzepacz PT, McCue M, Klein I, Levey GS, Greenhouse J. A psychiatric and neuropsychological study of patients with untreated Graves' disease. Gen Hosp Psychiatry 1988; 10(1): 49-55. [Crossref] [PubMed]

36. Trzepacz PT, Klein I, Roberts M, Greenhouse J, Levey GS. Graves' disease: an analysis of thyroid hormone levels and hyperthyroid signs and symptoms. Am J Med 1989; 87(5): 558-61. [Crossref] [PubMed] 